DOI: $10.19195 / 0137-1134.111 .14$

\title{
KRZYSZTOF PYCLIK
}

\section{„SĄ JESZCZE SĄDY WE WROCŁAWIU!"}

\author{
SPOTKANIE Z PROFESOREM ANDRZEJEM RZEPLIŃSKIM NA \\ WYDZIALE PRAWA, ADMINISTRACJI I EKONOMII UWR \\ (SALON PROFESORA DUDKA, 26 MAJA 2017 ROKU)
}

W nauce prawa [przed 1989 r.] autorzy akceptujący zasadę jedności władzy państwowej bądź wykluczają w ogóle ze słownika pojęcie niezawisłości sądownictwa ostając tylko przy pojęciu niezawisłości sędziego, bądź nadają nowe znaczenie pojęciu niezawisłości sądownictwa, rozumiejąc przez to „odrębność sądownictwa w stosunku do innych władz". Istotę tej odrębności sprowadza się do wydzielenia organizacyjnego w strukturze władzy. Rzecz jednak w tym, iż nie wiadomo wówczas, czy odrębność kolejnictwa w strukturze ministerstwa transportu nie ma tego charakteru. Akcentuje się bowiem wyodrębnienie techniczno-administracyjne, a nie konstytucyjne ${ }^{1}$.

W dniu 26 maja na Wydziale Prawa, Administracji i Ekonomii UWr odbyło się 580. spotkanie Salonu Profesora Dudka, którego gościem specjalnym był prof. dr hab. Andrzej Rzepliński, Prezes Trybunału Konstytucyjnego w latach 2010 2016, kierownik Katedry Kryminologii i Polityki Kryminalnej Instytutu Profilaktyki Społecznej i Resocjalizacji Wydziału Stosowanych Nauk Społecznych i Resocjalizacji Uniwersytetu Warszawskiego. Tematem wystąpienia prelegenta była Wolność człowieka jako wartość naszej ustawy ustaw. Gościowi specjalnemu towarzyszyła małżonka, prof. dr hab. Irena Rzeplińska (Zakład Kryminologii Instytutu Nauk Prawnych Polskiej Akademii Nauk). Przed prelekcją goście zostali przyjęci przez dziekana WPAiE UWr prof. dr hab. Karola Kiczkę. W rozmowie poruszono między innymi kwestię reform uczelni wyższych, planowanych przez Ministerstwo Nauki i Szkolnictwa Wyższego. Natomiast w spotkaniu Salonu, oprócz dziekana Wydziału Prawa, uczestniczyli: prorektor Uniwersytetu Wrocławskiego ds. finansów i rozwoju prof. dr hab. Wiesława Miemiec, dziekan Rady

1 A. Rzepliński, Sądownictwo w Polsce Ludowej. Między dyspozycyjnościa a niezawistościa, Warszawa 1989, s. 8-9. 
Okręgowej Izby Radców Prawnych we Wrocławiu i wiceprezes Krajowej Rady Radców Prawnych mec. Leszek Korczak, dziekan Rady Okręgowej Izby Radców Prawnych w Wałbrzychu mec. Sławomir Majka, były dziekan Okręgowej Rady Adwokackiej we Wrocławiu mec. Andrzej Malicki, sędzia Trybunału Konstytucyjnego prof. dr hab. Leon Kieres, sędzia Naczelnego Sądu Administracyjnego Mirosława Rozbicka-Ostrowska oraz dr Wojciech Jasiński z Biura Studiów i Analiz Sądu Najwyższego.

Profesor Rzepliński swoje wystąpienie rozpoczął od określenia wolności jako podstawowej wartości Konstytucji RP, wychodząc od zasady demokratycznego państwa prawa (art. 2 Konstytucji). Samo zaś pojęcie wolności pojawia się w tekście Konstytucji 81 razy (dla porównania w dłuższej o jedną trzecią konstytucji niemieckiej o wolności mówi się 33 razy). Częste używanie tego pojęcia przez ustrojodawcę wiąże się z pamięcią, gorzkich doświadczeń z czasów, gdy podstawowe wolności i prawa człowieka były w naszej Ojczyźnie łamane" (preambuła Konstytucji RP). Dlatego już w preambule ustawy zasadniczej mowa jest o pragnieniu zagwarantowania praw obywatelskich „na zawsze”. Konstytucja określona jest jako prawo podstawowe państwa „oparte na poszanowaniu wolności”. W dalszej części preambuła wspomina o „prawie do wolności” człowieka ze względu na jego przyrodzoną godność. Prelegent zdefiniował wolność jako obszar funkcjonowania każdego człowieka, do którego państwo (władze) w zasadzie nie ma dostępu, w którym autonomicznie regulujemy swoje funkcjonowanie w ramach tego obszaru i nie potrzebujemy żadnej pomocy ze strony władz publicznych. Z wolności korzystamy na własną odpowiedzialność i w granicach wartości konstytucyjnych bez potrzeby jakichkolwiek dodatkowych działań państwa. Wizja wolności w Konstytucji RP z 1997 roku jest odmienna od wizji Konstytucji PRL z 1952 roku, w której z reguły poszczególne wolności (ustęp 1) obwarowywano przesłankami należytego korzystania z nich (ustęp 2) („Ustęp drugi z reguły znosił wolność”). Jako ilustrację prof. Rzepliński podał art. 83 ust. 2 Konstytucji z 1952 roku, mówiący o sposobach „urzeczywistniania wolności słowa”. Odnosząc te spostrzeżenia do Konstytucji z 1997 roku, która w art. 5 głosi, że „Rzeczpospolita Polska [...] zapewnia wolności i prawa człowieka i obywatela”, mówca stwierdził: „Podejrzliwie podchodzę do przepisów, które w Konstytucji zawierają słowo »zapewnia«, a ono się pojawia bardzo często w naszej Konstytucji, bo 33 razy" (dla porównania: w Konstytucji RFN - 13 razy). Podobnie zapewnianie przez państwo wolności tworzenia i działania partii politycznych (art. 11 ust. 1) jest według Andrzeja Rzeplińskiego zbędne i wystarczyłoby zawarowanie tej wolności w art. 12, mówiącym o wolności tworzenia stowarzyszeń i ruchów obywatelskich. Również zapewnianie wolności prasy i innych środków społecznego przekazu niekoniecznie musi być kompetencją władz publicznych (art. 14).

Inspiracją dla Andrzeja Rzeplińskiego, także jako sędziego konstytucyjnego, była i jest mowa prezydenta USA Franklina D. Roosevelta, wygłoszona krótko 
przed przystąpieniem Stanów Zjednoczonych do wojny, 6 stycznia 1941 roku, poświęcona „,czterem wolnościom”:

1. wolności słowa, opinii i prasy („freedom of speech and expression”),

2. wolności religii (,freedom of every person to worship God in his own way"),

3. wolności od strachu przed własnym państwem (freedom from fear),

4. wolności od dojmującej potrzeby (lęku przed nędzą) (,freedom from want [...] which will secure to every nation a healthy peacetime life for its inhabitants") $)^{2}$.

Te wszystkie wolności za pomocą wielu słów zostały oddane w polskiej Konstytucji, choć - jak kontynuował prelegent — zbyt często opatrywane są dodatkiem o roli władz publicznych: „W kontekście wolności również w moim przekonaniu ustrojodawca niepotrzebnie używa pojęcia, że władze publiczne coś mogą albo czegoś nie mogą. Albo jest wolność, albo władzom publicznym — tak się wahamy - coś dajemy, czy wręcz przeciwnie"). Gość specjalny przytoczył wyrok TK z dnia 1 marca 2011 roku, P 21/09³, w którym Trybunał uznał, że wolność osobista człowieka i prawo do bezpieczeństwa osobistego gwarantują wolność każdego od arbitralności organów władz publicznych, chronią każdego od strachu przed własnym państwem, w tym także przed motywowanym politycznie pozbawieniem wolności w jakiejkolwiek formie.

Dalsze rozważania Andrzej Rzepliński poświęcił między innymi art. 22 (wolność działalności gospodarczej), art. 31 (zasada proporcjonalności) i art. 41 (nietykalność osobista i wolność osobista). Treść art. 31 ust. 1 („Wolność człowieka podlega ochronie prawnej") — która według prelegenta powinna być częścią art. 2 — nie jest na szczęście uzupełniona stwierdzeniem, że Rzeczpospolita Polska zapewni realizację tego wymogu. „Podlega ochronie prawnej” jest wprost nakazem dla ustawodawcy, żeby stworzył logiczny, zupełny system prawny, który będzie służył wolności ludzi. Jednocześnie każdy jest obowiązany szanować wolności i prawa innych. Nikogo nie wolno zmuszać do czynienia tego, czego prawo mu nie nakazuje (art. 31 ust. 2). Artykuł 31 ust. 3 ma podstawowe znaczenie dla ważenia różnych wartości przez Trybunał Konstytucyjny, kiedy poszukuje w każdej sprawie „złotego środka” w celu stwierdzenia, czy kwestionowany przepis jest zgodny z Konstytucją, czy nie. Ustęp 3 określa, jakie wartości trzeba brać pod uwagę przy ewentualnym ograniczeniu $\mathrm{w}$ zakresie korzystania $\mathrm{z}$ konstytucyjnych wolności i praw, a więc takie, które „są konieczne w demokratycznym państwie”. A demokratyczne państwo to przede wszystkim państwo, w którym są wolne i uczciwe wybory, w którym funkcjonuje demokracja parlamentarna, a funkcjonuje ona wówczas, gdy każdorazowa mniejszość polityczna w parla-

2 F.D. Roosevelt, Cztery wolności. Wystapienie przed Kongresem USA, 6 stycznia 1941, [w:] Wielkie mowy historii, t. 3, red. W. Władyka et al., Warszawa 2006, s. 120-127; Andrzej Rzepliński przywołuje „cztery wolności” również w wywiadzie udzielonym „Gazecie Wyborczej”: Rzepliński: przekraczajacy granice, wszelkie. Z prof. Andrzejem Rzeplińskim z rozmawia Tomasz Kwaśniewski, „Gazeta Wyborcza” 24-25 września 2016, s. 12-17.

3 OTK ZU 2011, nr 2-A, poz. 7. 
mencie ma realne możliwości współtworzenia prawa, „i nie dzieje się to na tej zasadzie: »Więcej pytań nie będzie, więcej wniosków nie będzie; kto jest 'za', kto jest 'przeciw'. Ogłaszam, że ustawa została przyjęta 237 głosami« — bo nie ma wtedy państwa demokratycznego: bez wolnego tworzenia prawa". Jednym z podstawowych obowiązków, zadań i misji sądu konstytucyjnego (tak wynika z orzecznictwa niemieckiego i austriackiego Trybunału Konstytucyjnego oraz francuskiej Rady Konstytucyjnej) jest ochrona mniejszości politycznych, bo bez tego nie ma dobrego prawa, jest dyktat, a nie prawo. Kolejną przesłanką badaną przez Trybunał Konstytucyjny jest „konieczność” ograniczeń, przy zastrzeżeniu, że ograniczenia te nie mogą naruszać istoty wolności i praw. Nawet wówczas gdy jest konieczne ograniczenie, to wolność zapisana w Konstytucji nie może być „wydrążona”, istota tego prawa bądź wolności nie może być „wycięta”.

W części dyskusyjnej spotkania gość specjalny pytany był o zasadność nieprzyjęcia przez prezydenta RP ślubowania od trzech sędziów Trybunału Konstytucyjnego wybranych przez Sejm VII kadencji (Romana Hausera, Andrzeja Jakubeckiego i Krzysztofa Ślebzaka), możliwość wywiedzenia subsydiarnego aktu oskarżenia w sprawach dotyczących podejrzenia działań zmierzających do zamachu stanu (art. 128 k.k.) czy też delegalizację partii politycznej stosującej metody niedemokratyczne (niezgodność z Konstytucją celów lub działalności partii politycznej: art. 13 Konstytucji RP i art. 44 ustawy z dnia 27 czerwca 1997 roku o partiach politycznych), ocenę zmiany zasad funkcjonowania służby cywilnej dokonanej ustawą z dnia 30 grudnia 2015 roku o zmianie ustawy o służbie cywilnej oraz niektórych innych ustaw ${ }^{4}$ czy planowanych zmian w ustawie o Krajowej Radzie Sądownictwa ${ }^{5}$ i Prawie o ustroju sądów powszechnych ${ }^{6}$. Pośród innych pytań pojawiła się też kwestia dopuszczalności zastosowania przez prezydenta RP prawa łaski na podstawie art. 139 Konstytucji RP wobec osób, których winę stwierdzono nieprawomocnym wyrokiem sądu (,abolicja indywidualna”, spotkanie z prof. A. Rze-

4 Dz.U. z 2016 r. poz. 34.

5 Ustawa z dnia 12 lipca 2017 roku o zmianie ustawy o Krajowej Radzie Sądownictwa oraz niektórych innych ustaw (druk sejmowy nr 1423 Sejmu VIII kadencji). Ustawa została w dniu 24 lipca 2017 roku zawetowana przez Prezydenta RP razem z równie kontrowersyjną ustawą z dnia 20 lipca 2017 roku o Sądzie Najwyższym (druk sejmowy nr 1727 Sejmu VIII kadencji). Zob. B. Chrabota, Ruch sprzeciwu prezydenta, „Rzeczpospolita” 25 lipca 2017, s. A1. Ta ostatnia ustawa stała się przedmiotem krytycznego stanowiska dziekanów czołowych polskich wydziałów prawa z dnia 17 lipca 2017, Stanowisko Dziekanów w sprawie poselskiego projektu ustawy o Sądzie Najwyższym, http://www.wpia.uw.edu.pl/wp-content/uploads/2017/07/Stanowisko-Dziekanów.pdf.

${ }^{6}$ Ustawa z dnia 12 lipca 2017 roku o zmianie ustawy — Prawo o ustroju sądów powszechnych (Dz.U. z 2017 r., poz. 1452). Por. Stanowisko Krajowej Rady Sądownictwa z dnia 28 lipca 2017 r. w przedmiocie ustawy z dnia 12 lipca 2017 r. o zmianie ustawy — Prawo o ustroju sądów powszechnych, http://www.krs.pl/pl/aktualnosci/d,2017,7/4929,stanowisko-krajowej-rady-sadownictwa-podjete-28lipca-2017-r-w-sprawie-zmiany-ustawy-prawo-o-ustroju-sadow-powszechnych oraz wcześniejsza Opinia Krajowej Rady Sądownictwa z dnia 12 maja 2017 r. w przedmiocie poselskiego projektu ustawy o zmianie ustawy - Prawo o ustroju sądów powszechnych oraz niektórych innych ustaw (druk sejmowy nr 1491), http:/www.krs.pl/pl/aktualnosci/d,2017,5/4782,opinia-krajowej-rady-sadownictwadotyczaca-poselskiego-projektu-zmiany-ustawy-prawo-o-ustroju-sadow-powszechnych. 
plińskim odbyło się jeszcze przed wydaniem przez Sąd Najwyższy uchwały z dnia 31 maja 2017 roku, I KZP 4/17, traktującej o tej kwestii ${ }^{7}$ ). Poruszono także zagadnienia wiążące się $\mathrm{z}$ orzeczeniem TK dotyczącym otwartych funduszy emerytalnych (wyrok z dnia 4 listopada 2015 roku, K 1/148), dopuszczalności kary śmierci i ,ustawy o bestiach" (ustawa z 22 listopada 2013 roku o postępowaniu wobec osób z zaburzeniami psychicznymi stwarzających zagrożenie życia, zdrowia lub wolności seksualnej innych osób ${ }^{9}$, co do której Trybunał wypowiedział się w wyroku z dnia 23 listopada 2016 roku, K 6/14 ${ }^{10}$ ), zasadność zmian w obecnie obowiązującej Konstytucji RP czy też usunięcia z urzędowego zbioru orzecznictwa Trybunału Konstytucyjnego wyroków z dnia 9 marca 2016 roku, K 47/1511, z dnia 11 sierpnia 2016 roku, K 39/16 ${ }^{12}$ i z dnia 7 listopada 2016 roku, K 44/16 ${ }^{13}$.

W obszernych odpowiedziach prof. Andrzej Rzepliński odniósł się do wszystkich zadanych mu pytań. Odpowiadając na zarzuty jednego z dyskutantów, że art. 139 Konstytucji RP jest nielogiczny, prof. Rzepliński ocenił, że przepisy, którym można zarzucić, że są wewnętrznie sprzeczne bądź sprzeczne z innymi przepisami, to „życie codzienne” każdej konstytucji, nie tylko polskiej. Im więcej słów ustrojodawca użyłby w art. 139, tym więcej byłoby problemów. Lecz w takich przypadkach oparcie znajdujemy w sądach konstytucyjnych (jako ilustrację prof. Rzepliński podał rozstrzygnięcie TK w sprawie „sporu o krzesło”, vide: postanowienie z dnia 20 maja 2009 roku, Kpt 2/08 ${ }^{14}$ ). Dekodowanie normy przepisu polega nie tylko na czytaniu tego przepisu, lecz także na uwzględnianiu innych orzeczeń, całego kontekstu konstytucyjnego. Takie zadanie jest czasami bardzo trudne, czasami niemal niemożliwe do dobrego wykonania przez sąd konstytucyjny w sporze, gdy na sali rozpraw są wszyscy główni aktorzy tego sporu. Niemniej jednak wspólnie (choćby dzięki uczestnictwu stron w postępowaniu) dochodzi się do jakiegoś logicznego rozumienia spornego przepisu. Wartością zaś samą w sobie jest „długie trwanie” regulacji konstytucyjnej.

Stwierdził także, że usuwanie wyroków jest przestępstwem przeciwko dokumentom, opisanym w art. 276 k.k. ${ }^{15}$ Odnośnie do proponowanych zmian w obec-

7 Uchwała składu siedmiu sędziów Izby Karnej Sądu Najwyższego z dnia 31 maja 2017 r., IKZP 4/17, http://www.sn.pl/sites/orzecznictwo/Orzeczenia3/IKZP 4-17.pdf; także: OSNKW 2017, nr7, poz. 37; Lex nr 2294441; Legalis nr 1603847.

8 OTK ZU 2015, nr 10-A, poz. 163.

9 Dz.U. z 2014 r. poz. 24 ze zm.

10 OTK ZU 2016, Seria A, poz. 98.

11 OTK ZU 2016, Seria A, poz. 2, także: Lex nr 2001897; Legalis nr 1406600.

12 OTK ZU 2016, Seria A, poz. 71, także: Lex nr 2086840; Legalis nr 1482365.

13 OTK ZU 2016, Seria A, poz. 86, także: Lex nr 2146792; Legalis nr 1522391.

14 OTK ZU 2009, nr 5-A, poz. 78.

15 Usunięcie wyroków TK z urzędowego zbioru orzeczeń to przestępstwo, „Karne24. com" 22 maja 2017, http://karne24.com/usuniecie-wyrokow-tk-urzedowego-zbioru-orzeczen-przestepstwo. Treść usuniętych wyroków została zamieszczona na stronie online Rzecznika Praw Obywatelskich oraz na portalach Monitor Konstytucyjny i konstytucyjny.pl: RPO publikuje usunięte z serwisu Trybunału Konstytucyjnego jego wyroki: w sprawach K 47/15, K 39/16, K 44/16, 2 czerwca 2017, https://www.rpo.gov.pl/pl/content/rpo-publikuje-usuniete-z-serwisu-trybunału-konstytu- 
nie obowiązującej Konstytucji RP, prelegent zadał retoryczne pytanie: „Czy ktoś, kto łamie Konstytucję, może ją zmieniać?".

Ustosunkowując się do pytań, prelegent przedstawił swoją ocenę bieżącej sytuacji:

Wobec „wygaszania” Konstytucji cała siła i nadzieja każdego z nas to są sędziowie i sądy. Tak że możemy tutaj powiedzieć: dopóki są sądy we Wrocławiu, dopóty jest prawo polskie i państwo polskie, dopóty jesteśmy obywatelami, a nie poddanymi. Nie musimy się bać swojego państwa, dopóki mamy sąd we Wrocławiu. [...] Czy jesteśmy państwem bezprawia? [...] Na to pytanie odpowiem tak: jesteśmy obywatelami państwa, w którym szereg podstawowych przepisów konstytucji zostało „wygaszonych”, ich nie ma. [...] Sędziowie muszą wiedzieć, jakie jest prawo. Konstytucja mówi, że podlegają tylko Konstytucji i ustawom. Ale jeżeli Konstytucja jest „,wygaszana”, to czemu podlegają? Którym przepisom? Które przepisy jeszcze w ogóle obowiązują? Gdy „centralny organ dyspozycji politycznej” mówi: „to może jeszcze być, ale to już nie”. Czyli sędziowie są zawieszeni i potem mogą być w przekonaniu ,wygaszaczy” słusznie oskarżani, że nie stosują się do ustaw i do Konstytucji. [...] Dopóki są sędziowie i będą znajdować prawo - a dobry sędzia znajdzie prawo do konkretnej sprawy, żeby wydać sprawiedliwy wyrok — dopóty nie ma jeszcze państwa bezprawia. Ale mamy „martwe strefy”, to jest prawda.

Podsumowując swe rozważania, były prezes Trybunału Konstytucyjnego Andrzej Rzepliński, trawestując opowieść o młynarzu z Sanssouci, powiedział:

Jeżeli będzie sąd w Warszawie, sąd we Wrocławiu, sąd w Gdańsku, to nie trzeba się bać represji za bezpośrednie stosowanie Konstytucji, jeżeli przepis ustawy będzie oczywiście niezgodny z Konstytucją i jeżeli Konstytucja jeszcze w tym obszarze obowiązuje. Ale jeżeli jej nie ma, bo został „wygaszony” jakiś przepis przez jego faktyczne wyeliminowanie, to jeszcze pozostaje nam prawo międzynarodowe, bo Konstytucja mówi, że umowy międzynarodowe są wprowadzane do polskiego systemu prawnego za zgodą ustawodawcy, czyli zawsze jest ustawa i zawsze jest treść tej normy prawa międzynarodowego czy prawa europejskiego ${ }^{16}$, jest orzecznictwo sądów strasburskiego i luksemburskiego. Tak że ciągle jestem absolutnie pewien, że mamy sądy w polskich miastach. Dziękuję.

Spotkanie z byłym prezesem Trybunału Konstytucyjnego, w którym oprócz prawników uczestniczyło wielu przedstawicieli innych dyscyplin naukowych, bez wątpienia unaoczniło, że problematyka konstytucyjna nie jest tak prosta, jak niektórzy chcieliby to widzieć.

cyjnego-wyroki-w-sprawach-k-4715-k-3916-k--4416; http://monitorkonstytucyjny.eu/archiwa/663, 2 czerwca 2017; Zaginione wyroki TK, 4 czerwca 2017, http://konstytucyjny.pl/?p=417.

${ }^{16} \mathrm{~W}$ tym kierunku idzie rozstrzygnięcie Sądu Apelacyjnego we Wrocławiu w wyroku z dnia 27 kwietnia 2017 r., II AKa 213/16, https://orzeczenia.ms.gov.pl/content/\$N/155000000001006 II_AKa_000213_2016_Uz_2017-04-27_002; OSA 2017, nr 4, poz. 6; Lex nr 2292416; Legalis nr 1604275. Omówienie wyroku: R. Baszuk, Ratyfikowana umowa i owoce z drzewa zatrutego, 5 czerwca 2017, http://www.radekbaszuk.pl/2017/06/ratyfikowana-umowa-i-owoce-z-drzewa.html; E. Ivanova, Owoce z zatrutego drzewa znowu nielegalne, „Rzeczpospolita” 7 czerwca 2017, s. C1, http://www. rp.pl/artykul/1324444-Dowody-zdobyte-z-przekroczeniem-granic-prowokacji-sa-nielegalne---wyrokSadu-Apelacyjnego-we-Wroclawiu.html; P. Kardas, M. Gutowski, Rozdwojenie jaźni ministra, „Rzeczpospolita” 13 czerwca 2017, s. C1, http://www.rp.pl/Sedziowie-i-sady/306189998-MaciejGutowski-i-Piotr-Kardas-dla-RZECZoPRAWIE---Rozdwojenie-jazni-ministra.html; R. Baszuk, Sąd przywrócit wewnętrzna spójność przepisowi o wykorzystaniu owoców z zatrutego drzewa, „Dziennik Gazeta Prawna” 21 czerwca 2017, http://prawo.gazetaprawna.pl/artykuly/1052212,owoce-z-zatrutegodrzewa-przepisy.html.

Przegląd Prawa i Administracji 111, 2017

(C) for this edition by CNS 